\title{
Study on Microbiologically Induced Corrosion of Concrete in Sewer Waste Water
}

\author{
William-Porbeni $\mathrm{D}^{1}$ and Gumus R. $\mathrm{H}^{\mathbf{2}}$ \\ Research Scholar ${ }^{1}$ and Professor $^{2}$ \\ ${ }^{1}$ Department of chemical Engineering \\ Faculty of Engineering, Niger Delta University \\ Wilberforce Island, Bayelsa State, Nigeria
}

\begin{abstract}
Concrete infrastructures that make up the sewer system exposed to sewer wastewaters are often subjected to microbial corrosion. The activity of sulfur-oxidizing bacteria Acidithiobacillus sp leads to the formation of biogenic sulfuric acid. The biogenic sulfuric acid plays a very vital role in sulfate attack on concrete leading to loss of concrete mass and deterioration. This paper presents the results of a laboratory study of concrete biodegradation by the activity of SOB A.thiooxidans. Concrete samples were immersed in real sewer wastewater under laboratory conditions for 14 months. Changes in chemical composition, weight loss, and sulfate concentration variation in the laboratory sewer were investigated. The influence of biogenic sulfuric acid on biocorrosion of concrete samples was determined in terms of weight loss, formation of corrosion by-products and bioleaching of $\mathrm{Ca}$ and Si ions leachates. The weight loss varied in the range $0.031-0.263 \mathrm{~mm} / \mathrm{yr}$. Changes in sample morphology and byproducts formed were observed by X-ray diffraction and SEM methods. The results of morphologic changes showed the formation of gypsum and ettringite with corrosion progression.
\end{abstract}

Key Words: Biogenic Acid, Corrosion, SOB, A-Thiooxidans, Concrete.

\section{INTRODUCTION}

The term microbiologically influenced corrosion (MIC) describe the increase in corrosion activity due to the presence and action of bacteria (Dexter, 2003). Processes that lead to deterioration and destruction of non-metallic materials due to the metabolic activity of micro-organisms are often referred to as biodeterioration. (Cwalina, 2014). Microbial induced corrosion (MIC) is considered to be a surface phenomenon as it influences the electrochemical processes actively and adversely affects the integrity of a metallic substratum. In understanding the mechanism of biocorrosion, the abundance and activities of micro-organism on the surfaces and in the bulk phase of the fluid is of key importance. (Geesey and White, 1990)

Microbial Induced Concrete Corrosion" (MICC) is a process whereby biogenic acid producing microorganisms accelerate the biodeterioration of concrete ( $\mathrm{Ma}$ et al, 2010).Biodeterioration of concrete elements results from their exposure to corrosive environments of soil, water, wastewater, and waste products. This results in deterioration in appearance, performance and functionality of buildings and structures. (Griffin et al., 1991; Paajanen et al. , 1994; Gaylarde and Morton, 1999; Saiz-Jimenez, 2003; Sanchez-Silva and Rosowsky, 2008). Biogenic sulphuric acid has been identified as a corrosive agent not only in wastewater treatment systems but also in corroding sewers (Idris et al, 2001:, Vincke, et al, 1999).

In concrete sewer systems, corrosion proceeds via a series of steps involving micro-organisms (Islander et al, 1991, Vollersten et $a l, 2008)$. The biodeterioration process is initiated by the chemical lowering of the alkaline $\mathrm{pH}$ of the moist concrete surfaces to a more neutral $\mathrm{pH}$ by carbonation. This initial step is followed by the colonization of the concrete surface by a variety of neutrophilic sulphide oxidizing bacteria and fungi. This process leads to the oxidation of the reduced sulphur compounds to dissociated sulphuric acid. The last step is characterized by the $\mathrm{pH}$ of the concrete surface falling below 2 as acidophilic organisms especially A.thiooxidans becomes dominant bacteria. The biogenic sulphuric acid produced by A. thiooxidans reacts with the surface of the concrete forming corrosion by products ettringite $\left(3 \mathrm{CaO}_{2} \mathrm{Al}_{2} \mathrm{O} \cdot 3 \mathrm{CaSO}_{4} \cdot 32 \mathrm{H}_{2} \mathrm{O}\right)$ and $\mathrm{gypsum}$ $\left(\mathrm{CaSO}_{4} \cdot 2 \mathrm{H}_{2} \mathrm{O}\right)$. (Okabe et al, 2007, O'Connell et al, 2010, Roberts et al, 2002). The aim of this study was to simulate real sewer conditions in a laboratory reactor to study the processes of MICC in sewer systems. 


\subsection{MATERIALS AND METHODS}

\subsection{SAMPLE COLLECTION}

Sewer wastewater used in the study was obtained from a 10 year old sewer chamber within the Edepie community of Yenagoa metropolis. Samples were collected in $10 \mathrm{~L}$ sterile container and transported to the laboratory. Samples were stored at $4^{\circ} \mathrm{C}$ prior to analysis. All chemical reagents used were of analytical grade. Corrosion experiments were performed in the Chemical engineering laboratory of the Niger Delta University.

\subsection{CONCRETE COUPONS}

Concrete coupons were prepared according to Eurocode standard (BS 1377: 1975) for concrete works for sewer systems. Form works were constructed with marine boards in the structural laboratory of the department of Civil Engineering Niger Delta University, in compliance with BS 1881-109:1983. The cement used during the course of this study was limestone Portland cement with a grade of 42.5 . This grade was chosen because it is the most commonly used cement for construction in Nigeria. The prepared concretes samples were cured in a curing tank for a total of 28 days in compliance with standards above. The dimensions were approximately $50 \mathrm{~mm}$ X $50 \mathrm{~mm}$ X $50 \mathrm{~mm}$ (length $X$ width $X$ thickness). The prepared concrete slabs were subjected to active MICC conditions.

\subsection{LABORATORY EXPERIMENTS}

To create and mimic conditions in a laboratory scale bio-sewer system, the system was properly insulated and made airtight enough to limit the dissolved oxygen concentration to create the sewer conditions for biogenic $\mathrm{H}_{2} \mathrm{~S}$ production and ultimately biogenic sulfuric acid. Increased air flow and water flow into the sewers may prevent these processes hence the sewer vents were further plugged to reduce dissolved oxygen (DO) concentration in the sewer system. The prepared coupons were subjected to active MICC conditions using real sewer wastewater sourced from a 10 year old sewer chamber with an initial water $\mathrm{pH}$ of 7.8. Growth of micro-organism, sulfate concentration and $\mathrm{pH}$ was monitored. The lab scale sewer was operated under cycles of anaerobic and aerobic conditions to simulate conditions in real sewer environment.

Laboratory experiments proceeded by immersing the concrete samples into real sewer waste water for 14 months. The raw sewer wastewater parameters tested are presented in Table $1 . \mathrm{pH}$ value of wastewater was 6.87 . The presence of sulphur-oxidizing bacteria Acidithiobacillus thiooxidans, heterotrophic bacteria and fungi was confirmed in the wastewater. The bacteria mentioned are responsible for the start and the course of biogenic sulphate attack (MICC) on the concrete samples. To provide an external source of energy and electron donor for the acidophilic micro-organisms, $2.5 \mathrm{mM}$ of thiosulphate solution was added to the sewer water (Mori et al, 1992). The $\mathrm{pH}$ was adjusted to 4.0. At time intervals, subsamples were withdrawn for $\mathrm{SO}_{4}{ }^{-2}$ measurement and microbial count analysis.

\subsection{SAMPLING}

2.4.1 Scanning electron microscopy SEM/XRD- Concrete coupons were periodically weighed and analyzed for corrosion by-products using SEM/XRD techniques. The changes in the concrete structure were monitored by XRD using Rigaku Miniflex 600 by Rigaku Co-operation Japan. Scanning electron microscopy was done using Phenom ProX by Phenom World Eindhoven Netherlands.

2.4.2 Chemical analysis- The $\mathrm{pH}$ of the laboratory sewer reactor was measured using a portable $\mathrm{pH}$ meter. For the determination of $\mathrm{SO}_{4}{ }^{2-}$, within the sewer wastewater samples were periodically withdrawn filtered and analyzed following APHA Standard Methods for Examination of Water and Wastewater, (APHA 1998)

2.4.3 Weight loss- Corrosion experiments were performed in model laboratory conditions simulating real sewage systems. Weight changes of concrete samples were determined by gravimetric analysis of corroded concrete. Surface precipitates (e.g., gypsum) were removed with a mild brush, the coupons were then dried in an oven at $80^{\circ} \mathrm{C}$ for 3 days, transferred to a chamber kept at a humidity of $100 \%$ for $24 \mathrm{~h}$, and then weighed. To obtain the weight loss, the mass of the concrete coupons obtained after exposure to sewer system was subtracted from the mass of the concrete coupons before biogenic degradation. The weight loss can be calculated by the expression below;

$$
W L=W o-W i
$$


Where $\mathrm{W}_{\mathrm{o}}$ and $\mathrm{W}_{\mathrm{i}}$ are the weight loss for concrete coupons before and after biogenic degradation.

After obtaining the weight loss data, the corrosion rate was calculated using the equation below

$C R(m m / y r)=534 W / D A T$

Where:

$\mathrm{CR}=$ corrosion rate in $\mathrm{mm} / \mathrm{yr}$.

$\mathrm{W}=$ weight loss in grams

$\mathrm{A}=$ area of specimen, inches

$\mathrm{T}=$ exposure time, $\mathrm{hr}$.

$\mathrm{D}=$ density of specimen, $\mathrm{g} / \mathrm{cm}^{3}$

\subsection{RESULTS AND DISCUSSION}

The chemical properties of the raw sewer waste water used in this study is presented in Table 1.

TABLE 1: Chemical analysis of raw wastewater samples.

\begin{tabular}{|l|l|}
\hline Parameter & $(\mathrm{mg} / \mathrm{l})$ \\
\hline $\begin{array}{l}\mathrm{pH} \\
\text { total suspended solids }\end{array}$ & $\begin{array}{l}6.87 \\
15.46\end{array}$ \\
\hline Conductivity & 2582 \\
\hline $\begin{array}{l}\text { Total amount of phosphorus } \\
\text { Sulfate (SO4) }\end{array}$ & 3.87 \\
\hline Nitrate & 79.93 \\
\hline Ammonia nitrogen & 46.63 \\
\hline Biological Oxygen Demand BOD5 & 202 \\
\hline Chemical Oxygen Demand COD & 549.14 \\
\hline
\end{tabular}

COD of the raw wastewater was measured as $1481.99 \mathrm{mg} / \mathrm{l}$ giving an estimate of organic matter present in a liter of sample sewer water. The BOD value was also estimated at $549.14 \mathrm{mg} / \mathrm{l}$. concentration of oxygen required for biological activities. The treatability of the wastewater measured as a concentration of ammonia in solution was estimated at $202 \mathrm{mg} \mathrm{NH}_{4} / \mathrm{l}$, with a nitrate value of $46.63 \mathrm{mg} / \mathrm{l}$. Phosphorus measured as orthophosphate was estimated at $3.87 \mathrm{mg} / \mathrm{l}$. This is an indication of nutrient availability for algal growth. TSS concentration was quantified (15.46 mg SS/l) at $\mathrm{pH}$ of 6.87 of raw wastewater. Sulphates concentration measured $(79.93 \mathrm{mg} / \mathrm{l})$ indicates the activities and presence of sulfur utilizing bacteria in the raw wastewater. See table 1 above.

\subsection{MICROBIAL INDUCED CONCRETE CORROSION}

Raw concrete coupons when initially produced have a $\mathrm{pH}$ of 11-12. Once immersed in the sewer water the surface $\mathrm{pH}$ is lowered by a series of chemical and biological processes taking place on the concrete surface. The $\mathrm{pH}$ is lowered to a $\mathrm{pH}$ of about 9 , a point where it becomes favourable for bacteria to colonize the surface using $\mathrm{H}_{2} \mathrm{~S}$ and oxygen as sources of energy to produce biogenic sulfuric acid. The sulfuric acid produced reacts with the concrete minerals leading to biodegradation. (Islander et al, 1991; Okabe et al, 2007).

The concrete $\mathrm{pH}$ was 12 before immersion into sewer wastewater environment of $\mathrm{pH} 6.87$. Reaction of the concrete and components of the sewer environment already containing SOB bacteria and concrete degradation by-products caused an increase in the $\mathrm{pH}$ of the concrete-sewer environment to a $\mathrm{pH}$ of 7.2 within the initial 60 days. The isolation and characterization of microbes identified the predominant acidophilic SOB in the sewer water as Acidithiobacillus thiooxidans (T. thiooxidans). No significant loss in the weight of the concrete coupons was observed during the initial 60 days due to slow growth of the SOB and neutralization reaction on the concrete surface. 


\subsection{SEM AND XRD ANALYSIS}

SEM images together with the EDAX results gave a picture of how the concrete base materials were modified during the course of study. The results showed patterns of silicate and carbonate aggregates embedded in the concrete matrix.

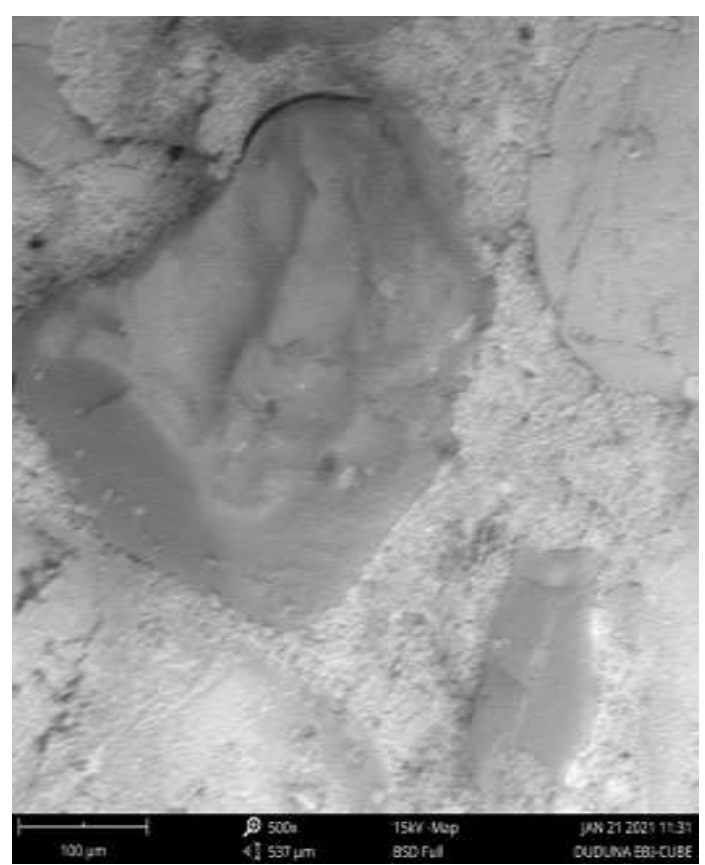

Figure 1: SEM AFTER 14 MONTHS

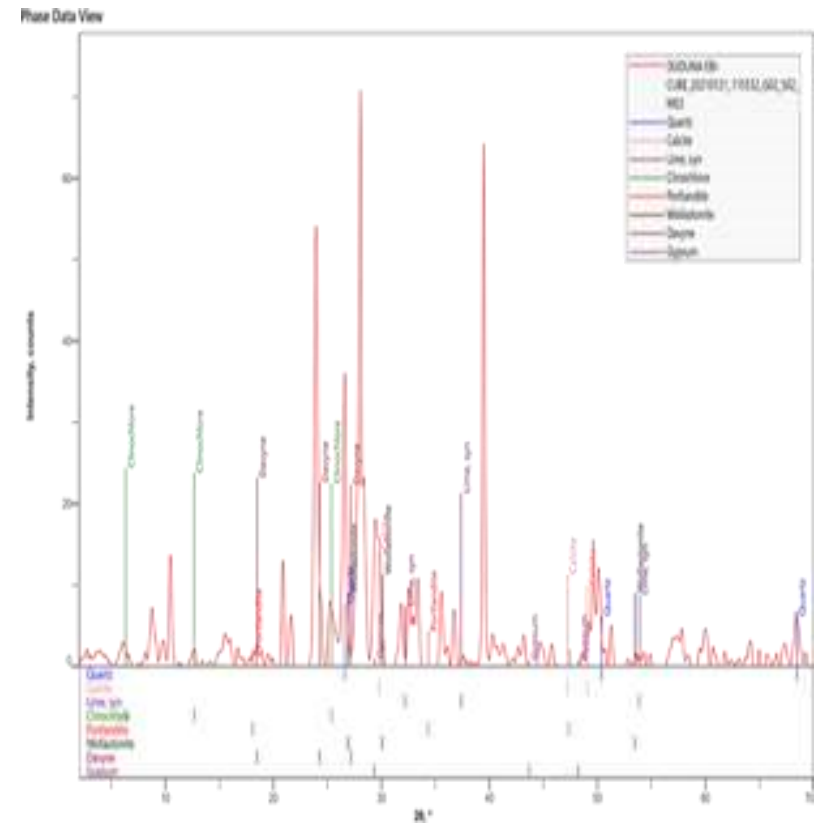

Figure 2: XRD AFTER 14 MONTHS

The element distribution showed the cement matrix to be dominated by high concentration of calcium and silica atoms as $33.72 \%$ and $2.45 \%$ respectively. Low abundance of $\mathrm{Al}, \mathrm{Fe}$, Sulfur and magnesium was also recorded. After 80 days of immersion in the raw sewer water, an increase in calcium level to $68.79 \%$ and silicon to $7.16 \%$ was observed. The crystals identified to be present in the raw concrete before MICC are: portlandite, quartz, calcite, biotite and microcline. The intensity of the portlandite was 2500 at $18^{\circ}, 35^{\circ}, 47^{\circ}$ and $52^{\circ}$. The quartz crystals had a maximum intensity of 5800 at $26^{\circ}$. Calcite had a maximum intensity of 3900 at $29^{\circ}$ with Biotite crystals having a maximum intensity of 5800 at $26^{\circ}$. After an initial 80 days period crystals of quartz, calcite and portlandite were still present in the concrete. Due to the slow rate of concrete solubilization, the intensity and presence of the identified crystals remained relatively unchanged.

\subsection{CORROSION PRODUCTS}

Biogenic acid degradation of concrete materials leads to the formation of corrosion by-products gypsum $\left(\mathrm{CaSO}_{4}\right)$ and ettringite $\left(3 \mathrm{CaO} \cdot \mathrm{Al}_{2} \mathrm{O}_{3} \cdot \mathrm{CaSO}_{4} \cdot 12 \mathrm{H}_{2} \mathrm{O}\right)$. Results of XRD analysis on the concrete samples after 14 months indicated the presence of ettringite $\left(3 \mathrm{CaO} \cdot \mathrm{Al}_{2} \mathrm{O}_{3} \cdot \mathrm{CaSO}_{4} \cdot 12 \mathrm{H}_{2} \mathrm{O}\right)$ a corrosion by-product and surface precipitate. Ettringite is a crystalline compound formed by cement hydration and biogenic sulfuric acid attack on the concrete. The ettringite once formed increases the internal pressure of the concrete due to its large volume leading to the formation of micro and macro cracks. (Aviam et al, 2004, Wei et $a l$, 2013). The formation of corrosion by-product has been reportedly dependent on the $\mathrm{pH}$. Mori T, et al. (1992) reported the dependence of formation of crystals on the sewer $\mathrm{pH}(\mathrm{pH}<3$ for gypsum and $\mathrm{pH}>3$ for ettringite). In deeper sections of the concrete coupons under acid attack it has been observed that only limited amounts of ettringite is formed as long as the $\mathrm{pH}$ is high enough to maintain its stability. (Skalny et al, 2002). Similar observation of ettringite inability to survive under acidic conditions was observed in this study.

Figures 1 and 2 shows the formation of gypsum on the concrete coupon. Parker (1945) described gypsum as a white putty-like deposit, moist, flaky and is easily removed from the concrete surface. Davis et al, 1998 described gypsum as a 'white mushy substance with no cohesive properties and has the consistency of a cottage cheese'. Reactions of cement hydration products and the biogenic sulfuric acid in sewers produces gypsum.

Gypsum was produced on the surface of concrete materials at $\mathrm{pH}$ levels below 3. The formation of gypsum is considered to be one of the primary mechanisms involved in the biogenic acid corrosion of concrete leading to a loss of cohesion in cement compounds (George et al, 2012, Hewayde et al, 2006, Mori et al, 1992). The gradual formation and build-up of gypsum in the cement matrix is believed to act as a barrier and provides a protective layer for the concrete preventing further penetration of 
biogenic acid into the concrete hence slowing the attack and the biogenic deterioration process. Removing this layer further exposes the concrete to acid attack thus accelerating the corrosion damage to the surface. (Rendell and Jauberthie, 1999). However, it has been reported that the rougher surface area formed by the gypsum leads to a higher surface area exposed to biogenic acid attack. (Vollertsen, et al 2008).

\subsection{CORROSION RATE}

Biogenic corrosion of concrete in sewers is a very slow process with corrosion rates ranging from $1 \mathrm{~mm} / \mathrm{yr}$ to $5 \mathrm{~mm} / \mathrm{yr}$ requiring several years for corrosion to take place. This study was performed by creating optimal conditions for bacterial growth that may not always be present in real sewer systems so as to accelerate the corrosion rates. This study differs from the typical laboratory approach in the way real sewers wastewater was used. Additionally the use of thiosulphate solution as a source of energy for the acidophiles as against the direct bubbling of $\mathrm{H}_{2} \mathrm{~S}$ gas through the sewer as reported in studies (Guitterez-Padilla et al, 2010, Mori, et al, 1991). A comparison of the corrosion rates observed in this study to that observed in several others is presented here-in.

\section{TABLE 2: Corrosion rates in laboratory and Field studies}

\begin{tabular}{|l|l|l|l|}
\hline S/N & Site & Corrosion rates $(\mathbf{m m} / \mathbf{y r})$ & Author \\
\hline 1 & Lab & $0.08-0.208$ & Guiterrez-padilla et al,2010 \\
\hline 2 & Lab & $1.6-4.3$ & De-ballie et al, 2000 \\
\hline 3 & Lab & $\mathbf{0 . 0 3 1 - 0 . 2 6 3}$ & Present study 2020 \\
\hline 4 & LAB & $2-3$ & Jiang et al, 2014b \\
\hline 5 & Lab & $0.18-2.19$ & $\begin{array}{l}\text { Nnadi and Lizarazo-Marriaga, } \\
2013\end{array}$ \\
\hline 6 & Lab & 16 & A $\epsilon$ Soy et al, 2002 \\
\hline 7 & Field & $4.3-4.7$ & Mori et al, 1992 \\
\hline
\end{tabular}

Concrete weight loss was determined as a parameter to judge concrete deterioration. Weight loss measurements showed an increase in concrete weight at the beginning of the study due to liquid saturation in the internal concrete pores; this provided for an increase in the internal pressure of the concrete. During this initial stages of exposure to the sewer wastewaters, there were no significant difference in parameters that could be related to MICC biodegradation. When further exposed to sewer environment with sulfate and biogenic acidophilic micro-organism, weight loss of the concrete was observed. Biogenic corrosion of concrete samples has been previously characterized by the weight loss method (Gutiérrez-Padilla et al. 2010,). Sand, et al. (1997) corroded test blocks by periodically spraying with Thiobacilli cultures; it was observed that severely corroded specimens had a weight loss of almost $6 \%$ after 15 months exposure to the bacterial cultures. (Sand et al, 1997). Sewage flow in sewer systems accelerates the rate of concrete corrosion as a result of the removal of deteriorated and corroded material from the concrete surface thus exposing new surfaces to corrosion (Wei et al, 2013). The recorded low corrosion rates in this study can be as a result of the semi-batch operation of the sewer reactor compared to flow systems.

\subsection{CHEMICAL COMPOSITION VARIATION}

The variations in the chemical composition of concrete before and after corrosion was observed and presented in Figure 3. As shown in the Figures, there was a marked variation in the chemical composition of the concrete with time. However there was a decrease in calcium ion concentration and an increase in silicon ions after exposure to sewer environment for 14 months. 


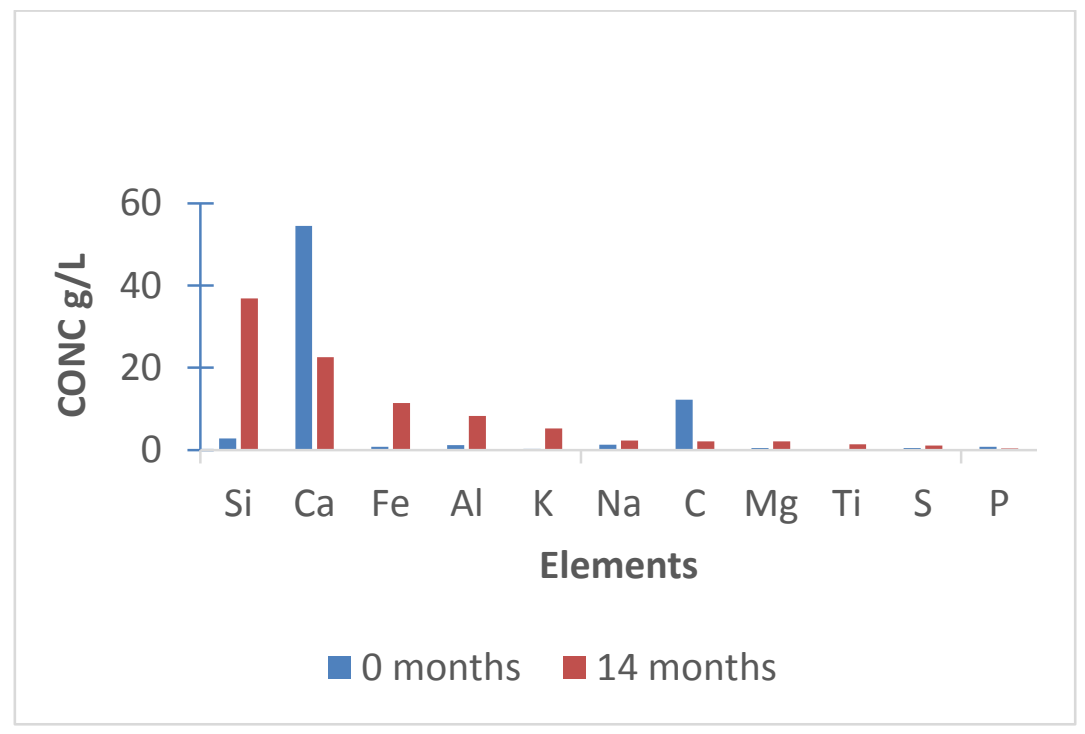

Figure 3: Concrete chemical composition variation with time.

Biocorrosion of the concrete led to a significant decrease in calcium ion as a result of bioleaching from the concrete matrix and biogenic reactions of calcium and biogenic sulfuric acid in solution. This decrease results in surface compounds being formed by the reaction of the calcium compounds and the biogenic sulfuric acid. Increase in silicon ions was observed when compared with the initial concentration. The final concentration of the silicon ions was $32 \mathrm{~g} / \mathrm{l}$. Similar results were reported by Estokova et el, 2011 and Harbulakova et al, 2013.

\section{7 pH VARIATION WITH TIME}

Considerable changes in $\mathrm{pH}$ were observed during the duration of the study and is presented in figure 4. This was due to the action of Acidithiobacillus Thiooxidans. Biogenic acid degradation of the cement matrix leads to the release of alkali compounds, reaction of these compounds with sulfuric acid in the sewer system leads to an increase in $\mathrm{pH}$.

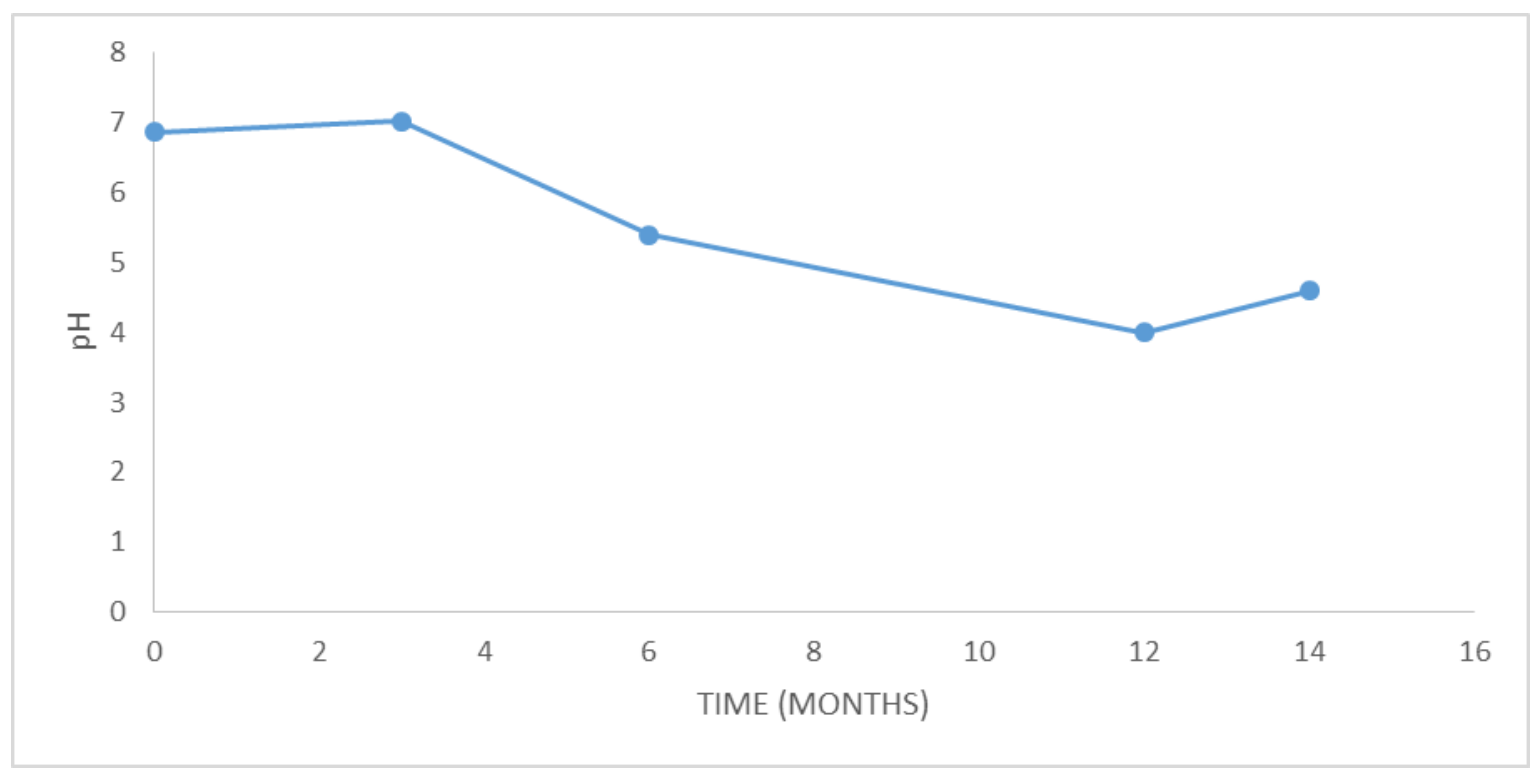

Figure 4: VARIATION OF pH WITH TIME

This rise in $\mathrm{pH}$ was controlled by addition of thiosulfate solution to the sewer system which also doubles as a source of energy for the predominantly Acidithiobacillus-Thiooxidans. Okabe et al, 2007 suggested that the decrease in pH during MICC in sewer systems is facilitated by microbial activities in addition to the abiotic neutralization of the concrete surface with $\mathrm{CO}_{2}$ and $\mathrm{H}_{2} \mathrm{~S}$. 


\subsection{SULFATE}

The activity of sulfur oxidizing bacteria produces sulfate as its main by-products. A plot of sulfate variation with time is presented in Figure 5. In sewer systems, sulfide reacts with oxygen at $\mathrm{pH}$ values of 6 and above. This reaction results in the formation of thiosulfate $\left(\mathrm{S}_{2} \mathrm{O}_{3}{ }^{2-}\right)$, sulfite $\left(\mathrm{SO}_{3}{ }^{-}\right)$and elemental sulfur utilized by $\mathrm{SOB}$ for growth and metabolism.

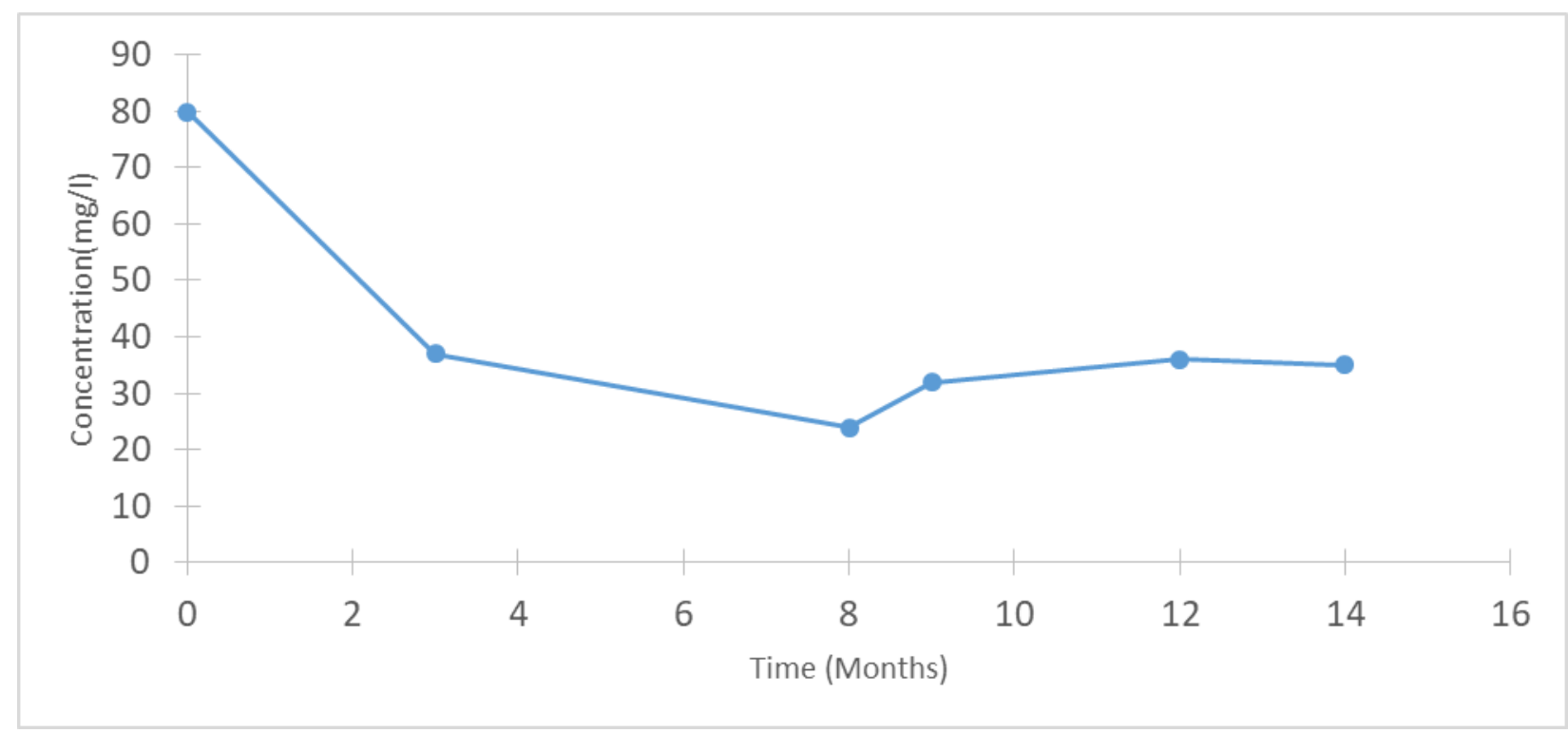

Figure 5: SULFATE VARIATION WITH TIME

In this study, the initial sulfate concentration decreased from $78 \mathrm{~g} / 1$ to $32 \mathrm{~g} / \mathrm{l}$ within the initial 3 months period. This drop in sulfate is likely due to the neutralization reaction of the concrete coupons in the wastewater system. To compensate for this drop and provide an additional source of energy for the SOB, solution of thiosulfate was introduced into the system as a source of sulfate to aid in growth of acidophiles. With a decrease in $\mathrm{pH}$ within the sewer system elemental sulfur was further oxidized to sulfate. Sulfur being a temporary intermediate of sulfide oxidation is finally oxidized to sulfate. Sulfate oxidation is only favored by a relatively low pH values 3-4. (Okabe et al, 2007, Jensen et al, 2009, Joseph et al, 2012). This low pH and the production of sulfate and subsequently sulfuric acid leads to the formation of corrosion by-product ettringite on the concrete coupons.

\subsection{CONCLUSION}

$>$ The results obtained closely fits with the proposed mechanism for MICC in sewers.

$>$ The gradual drop in $\mathrm{pH}$ from 6.87 to 3.0 allowed for the growth of SOB Acidithiobacillus thiooxidans.

$>$ The formation of corrosion by-products gypsum and Ettringite on the concrete surface with the progression of the process supports the correlation between $\mathrm{pH}$, bacteria activity and sulfate on the rate of corrosion and formation of byproducts.

$>$ Results obtained supports the mechanism of concrete corrosion in sewers and is comparable to those obtained in studies under laboratory conditions.

D The biodeterioration of the concrete was caused the presence of biogenic sulfuric acid produced by Acidithiobacillus thiooxidans.

\section{REFERENCES}

[1] American Public Health Association; American Water Works Association; Water Environment Federation (1998) Standard Methods for the Examination of Water and Wastewater, 20th ed.; American Public Health Association: Washington, D.C.

[2] Aviam O., Bar-Nes G., Zeiri Y. and Sivan A. (2004) Accelerated biodegradation of cement by sulfur-oxidizing bacteria as a bioassay for evaluating immobilization of low-level radioactive waste. Appl Environ Microbiol 70:6031-6036.

[3] Beech, I.B. and Sunner, J. (2004) Biocorrosion: towards understanding interactions between biofilms and metals. Current Opinion in Biotechnology 2004, 15:181-186. 
[4] Cwalina, B., (2014). 'Biodeterioration of concrete, bricks and other mineral based building materials'. Understanding Biocorrosion. (Available from http://dx.doi.org/10.153319781782421252.3.218).

[5] De-Belie N, Debruyckere M, Van-Nieuwenburg, and D. and De-Blaere B. (1997). Attack of concrete floors in pig houses by feed acids: influence of fly ash addition and cement-bound surface layers. Journal. Agricultural engineering research. 6892):101-108

[6] Dexter, S.C. (2003)" Microbiologically influenced corrosion, corrosion: fundamentals, testing \& protection", Volume 13A, ASM Hand book, ASM. International, pp. 398-416.

[7] Estokovaa, A., Harbulakovab, V.O., Luptakovac, A., and Stevulovaa, N., (2012). 'Study of the deterioration of concrete influenced by biogenic sulphate attack'. Proceedia engineering 42: 1731-1738.

[8] Gaylarde, C.C. and Morton, L.H.G. (1999). Deteriogenic biofilms on buildings and their control: a review'. Biofouling, 14 (1):59- 74 .

[9] George, R.P., Vishwakarma, V., Samal, S.S. and Mudali, U.K., (2012). Current understanding and future approaches for controlling microbially influenced concrete corrosion: a review. Concrete Research Letters, 3 (3):491 - 506.

[10] Griffin, P.S., Indictor, N. and Koestler, R.J. (1991) 'The biodeterioration of stone: a review of deterioration mechanisms, conservation case histories and treatment', International Biodeterioration, 28, 187 - 207.

[11] Gutiérrez-Padilla, M.G.D., Bielefeldt A., Ovtchinnikov S., Hernandez M., and Silverstein J., (2010). Biogenic sulfuric acid attack on different types of commercially produced concrete sewer pipes. Cement. Concr. Res. 40:293-301.

[12] Harbulakova, V.O., Estokova, A., Stevulova, N., Luptakova,A., and Foraiova, K. (2013). Current trends in investigation of concrete biodeterioration. Proceedia engineering 65:346-351.

[13] Idriss A.F., Negi S.C., Jofriet J.C., and Hayward G.L., (2001). Corrosion of steel reinforcement in mortar specimens exposed to hydrogen sulphide, part 1: impressed voltage and electrochemical potential tests. J. Agr. Eng. Res.79:223-230.

[14] Islander, R.L., Devinny, J.S., Mansfield, F., Postyn, A. and Shih, H. (1999). Microbial ecology of crown corrosion in sewers. J.Environ.Eng. 117:751-770.

[15] Jensen, H.S., 2009. PhD Thesis; Hydrogen Sulfide Induced Concrete Corrosion of Sewer Networks. Aalborg University.

[16] Jiang, G., Sun, X., Keller, J., and Bond, P.L., 2015. Identification of controlling factors for the initiation of corrosion of fresh concrete sewers. Water. Res. 80:30-40.

[17] Ma, G., Gutiérrez-Padilla, D., Bielefeldt, A., Ovtchinnikov, S., Hernandez, M., and Silverstein, J., (2010).' Biogenic sulfuric acid attack on different types of commercially produced concrete sewer pipes'. Cement. Concr. Res. 40: $293-301$.

[18] Mori,T., Koga,M., Hikosaka, Y., Nonaka, T., Mishina, F., Sakai, Y., and Koizumi, J. (1991) Microbial corrosion of concrete sewer pipes, H2S production from sediments and determination of corrosion rate, Water Science and Technology 23 (79):1275-1282.

[19] Mori, T. Nonaka, T., Tazaki, K. Koga, M., Hikosaka, Y. and Noda, S. (1992) Interactions of nutrients, moisture, and pH on microbial corrosion of concrete sewer pipe, Water Resources 26 (1): 29-37.s

[20] Nnadi E.O. and Lizarazo-Marriaga, L. (2013) “Acid Corrosion of Plain and Reinforced Concrete Sewage Systems,” J. of Materials in Civil Engineering, ASCE, 25, pp. 1353-1356.

[21] O 'Connell, M., McNally, C. and Richardson, M.G. (2010). Biochemical attack on concrete in wastewater applications: a state of the art review'. Cement and Concrete Composites, 32 (7):479 - 485.

[22] Okabe S., Odagiri M., Ito T., and Satoh H. (2007) Succession of sulphur-oxidizing bacteria in the microbial community on corroding concrete in sewer system. Appl. Env. Microbiol. 73:971-980. 
International Journal of Advances in Scientific Research and Engineering (ijasre), Vol 7 (9), September -2021

[23] Paajanen, L., Ritschkoff, A.C., and Viitanen, H. (1994) Effect of Insulation Materials on the Biodeterioration of Buildings, Espoo, VTT Publ . pp 791.

[24] Rendell F, Jauberthie R. The deterioration of mortar in sulphate environments. Constr Build Mater 1999; 13(6):321-327

[25] Roberts, D.J., Nica, D., Zuo, G. and Davis, J.L. (2002) 'Quantifying microbially induced deterioration of concrete: initial studies'. Int. Biodeter. Biodegrad. 49:227 - 234.

[26] Rose, A.H. (1981) Microbial Biodeterioration. Economic Microbiology 6. Academic Press, London. Pp 35-80.

[27] Sanchez-Silva, M. and Rosowsky, D.V. (2008). 'Biodeterioration of construction materials: state of the art and future challenges'. Journal of Materials in Civil Engineering, ASCE, 2008 pp 352 - 365. Surface analysis techniques for investigating biocorrosion.

[28] Sand, W. (1997). Microbial mechanism of deterioration of inorganic substrates: a general mechanistic overview. International Biodeterioration and Biodegradation. 40(2-4):183-190.

[29] Saiz-Jimenez, C. (2003) 'Biodeterioration: an overview of the state-of-the-art and assessment of future directions ' ( available from: http://www.google.pl/search?q = cache: jxplYfxPpSMJ :www.arcchip.cz/w08/w08_saiz_jimenez.pdf + \%22biodeterioration\%22, + \%22stone\%22, + \%22mechanism\%22\&hl $=$ pl\&ie $=$ UTF-8 .

[30] Skalny J, Marchand J, and Odler I. Sulfate attack on concrete. London, Spon Press, 2002.

[31] Vincke E., Verstichel S., Monteny J., and Verstraete W. (1999). A new test procedure for biogenic sulfuric acid corrosion of concrete. Biodegrad 10: 421-28.

[32] Vollertsen, J., Nielsen, A.H., Jensen, H.S., Wium-Andersen, T., Hvitved-Jacobsen, T., (2008). Corrosion of concrete sewers the kinetics of hydrogen sulfide oxidation. Sci.Total. Environ. 394: 162-170.

[33] Wei, S., Jiang, Z., Liu, H., Zhou, D. and Sanchez-Silva, M. (2013) Microbiologically induced deterioration of concrete - a review, Braz. J. Microbiol. 44 (4) (2013) 1001- 1007 